\title{
Towards Better Social Housing Policy Based on Residents' Satisfaction: A Case Study at Sendangmulyo, Semarang, Indonesia
}

\author{
Nany Yuliastuti ${ }^{1} \&$ Yudhi Widiastomo ${ }^{1}$ \\ ${ }^{1}$ Department of Urban and Regional Planning, Diponegoro University, Semarang, Indonesia \\ Correspondence: Nany Yuliastuti, Department of Urban and Regional Planning, Diponegoro University, \\ Semarang, Indonesia. Tel: 62-8-1127-6602. E-mail: n.yuliastuti@undip.ac.id
}

Received: January 21, 2015 Accepted: January 28, 2015 Online Published: March 30, 2015

doi:10.5539/jsd.v8n2p149

URL: http://dx.doi.org/10.5539/jsd.v8n2p149

\begin{abstract}
Sendangmulyo housing is one of the social housings for middle-income community in Semarang City built by the Indonesian National Housing Authority (PERUMNAS) in 1994. It was built based on the PERUMNAS social housing policy to provide houses for middle-income communities with affordable prices. However, Sendangmulyo inhabitants have limited fund for preservation of the environment. The limitation has caused environmental degradation, i.e., damage roads in several locations, poorly maintained drainage, poor water quality, and inadequate residential facilities. Based on this condition, this research aims to measure the satisfaction level of the residents in Sendangmulyo Housing and the implications for better social housing policy in the future. The results of this research show that the average level of residents' satisfaction is satisfying, with satisfaction index score of $58.1 \%$. The high satisfaction level is influenced by the quality of community relations with an index of $73.4 \%$, and the low one is influenced by the quality of the environment facilities with an index of $49.8 \%$. The high quality of community relations is caused by the good neighborly relations and social activities that still exist in the neighborhood. It has become a major factor for the social housing residents to stay and survive in the neighborhood.
\end{abstract}

Keywords: residents' satisfaction, social housing, social interactions

\section{Introduction}

Urban population is increasing due to urbanization that has caused higher needs for housing. However, the supply of land is becoming more limited. This condition has caused the increasing prices of houses built by the private sector. The prices are too expensive and unaffordable for low and middle-income communities. Therefore comes the concept of social housing by the government for low and middle-income communities. Housing for low and middle-income communities is the result of a complex process, in which consideration of the needs, limitations, and ability is important. The term of social housing has emerged since the early $20^{\text {th }}$ century as a movement of social emancipation of the workers in Europe. Social housing is a non-profit procurement for houses, and it rests on two main pillars of state intervention and community empowerment.

In Indonesia, the social housing is provided by PERUMNAS (Indonesian National Housing Authority) through the policy of small type and affordable price houses. PERUMNAS has provided houses for low and middle-income people through the construction of large-scale social housing in Semarang City. Semarang City is important for the PERUMNAS because its population is more than 1.5 million people (Semarang Statistics Centre, 2013). That is why, PERUMNAS has built social housings in the suburbs of Semarang City, and one of them is Sendangmulyo Housing.

However, the existence of social housing cannot be separated from environmental problems. On the other hand, as a formal and planned housing, Sendangmulyo, which has been built for 20 years, has a slow or stagnant development if compared with Banyumanik and Tlogosari Housing, another social housing built by PERUMNAS in a Semarang suburb (Yuliastuti \& Said, 2013). It is most probably because Sendangmulyo has many environmental problems such as lack of facilities and poorly maintained infrastructure. As a mass built housing, the condition of Sendangmulyo cannot be separated from the problems of environmental degradation (Yuliastuti \& Said, 2013). It can be seen from the number of damage roads in several locations, poorly maintained drainage, poor water quality, and inadequate residential facilities. In addition, Sendangmulyo also has $5.5 \%$ of unoccupied houses and $14.5 \%$ of undeveloped and untreated plots. 
Therefore, it is necessary to know the residents' satisfaction based on housing policy implementation that has been set. The aim of this study is twofold: (1) to measure the residents' satisfaction with the Sendangmulyo social housing and (2) to discuss the implications for better social housing policy in the future. The object of this research is Sendangmulyo housing located in Sendangmulyo Sub-district, Tembalang District of Semarang City. This research used a quantitative approach.

This paper is organized into six parts. Following this introduction, part two is about social housing policy by PERUMNAS. Part three is about the literature review and concept of housing satisfaction, and part four is about methods in this study. Part five presents and discusses the findings, and finally part six concludes.

\section{Sendangmulyo: An Overview}

Sendangmulyo social housing was built by PERUMNAS in 1994 with 2,081 houses. PERUMNAS has built a modest housing with the 21,36 and 45 house types, equipped with facilities and infrastructure. Sendangmulyo has a distance of about 4.5 kilometers to the Tembalang District Office and 11 kilometers to the Central Bussiness District (CBD) of Semarang. Sendangmulyo has 537.493 square meters / 53.75 hectares or about 13\% of the Sendangmulyo Sub-district area. The neighborhood comprises six blocks of residential areas called "Rukun Warga" (RW). RW is a block in a residential area that its formation is defined by the Sub-district's government through local community meetings. As a community institution, an RW comprises smaller neighborhood institutions called "Rukun Tetangga" (RT), which is a group of several neighboring households. Sendangmulyo housing consists of six RWs called RW 15, RW 19, RW 20 RW 21, RW 22, and RW 24 (see Figure 1).

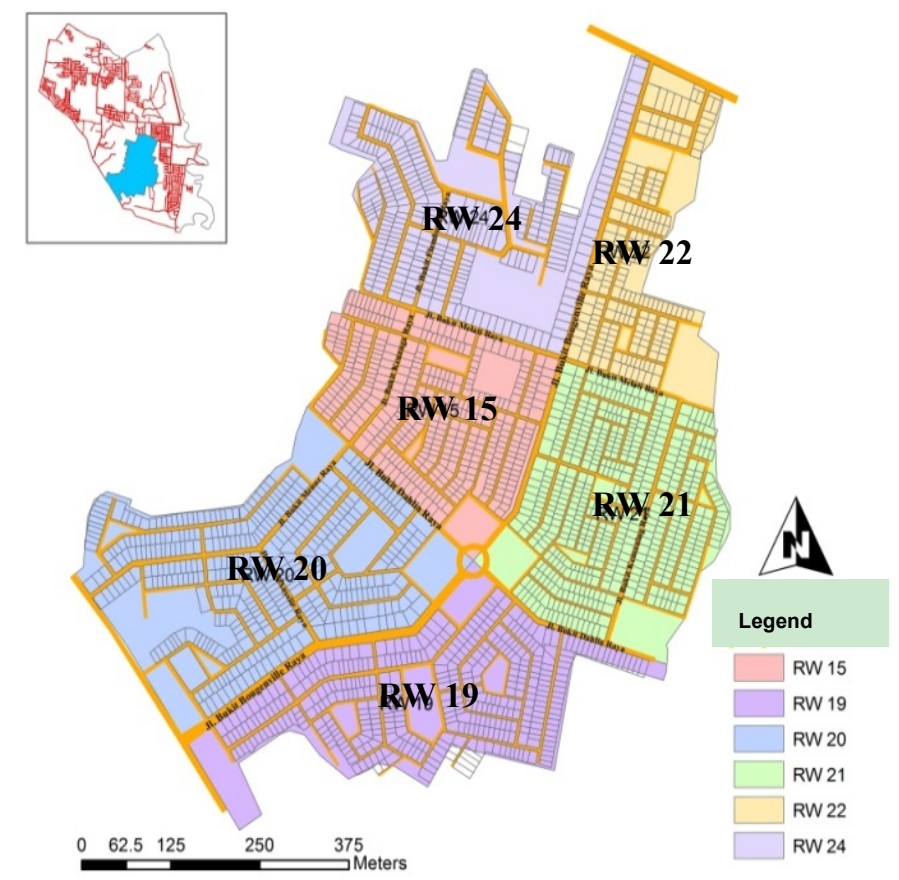

Figure 1.Siteplan of Sendangmulyo's housing

\section{Social Housing Policy by PERUMNAS}

In the formal sector, the government is the main actor in the Indonesian housing development. In 1974, the government through the PERUMNAS (Indonesian National Housing Authority) has provided mass housing development that aims to meet the housing needs of the people. According to Panuju (1999) PERUMNAS is responsible for the housing procurement, starting from the land acquisition, site and construction plans, preparation of the land, to the implementation of development plans and the maintenance of physical environment. PERUMNAS, along with Bank Tabungan Negara, has been tasked to deliver mortgage (Kredit Kepemilikan Rumah/KPR), which is subsidized by the government to help the low and middle-income communities.

Although the social housing is more concerned on obtaining an affordable price for the low and middle-income 
people, the houses should meet the standards set by the government. Indonesia has set the standard of house space as nine square meters/person (Table 1).

Table 1. Minimum standards of healthy house (KPR-BTN)

\begin{tabular}{|c|c|c|c|c|}
\hline No & Space used & $\begin{array}{c}\text { Minimum width } \\
\text { (meters) }\end{array}$ & $\begin{array}{c}\text { Minimum area } \\
\text { (meters) }\end{array}$ & $\begin{array}{l}\text { Ceiling/Plafond } \\
\text { height (meters) }\end{array}$ \\
\hline \multirow{2}{*}{1} & Main bedroom & 3 & 9 & +2.40 \\
\hline & Children bedroom & 2 & 6 & +2.40 \\
\hline \multirow{3}{*}{2} & Lounge \& dining room & 3 & 12 & +2.40 \\
\hline & Join & 2.5 & 7.5 & +2.40 \\
\hline & Separated & & & \\
\hline 3 & Kitchen & 1.5 & 3 & +2.40 \\
\hline \multirow{6}{*}{4} & Bathroom & & & \\
\hline & Square & 1.5 & 2.25 & +2.00 \\
\hline & lengthwise & 1 & 2.70 & +2.00 \\
\hline & Separated & 1 & & \\
\hline & Bathroom & 1 & 2.10 & +2.00 \\
\hline & Water Closet & & 1.40 & +2.00 \\
\hline
\end{tabular}

Source : KPR-BTN, 2007

\section{Concept of Resident's Satisfaction in Social Housing}

A house is a place that helps to meet the basic physiological needs and helps people to survive (Hablemitoglu et al., 2010). Turner (1976) states that a house must be associated with the persons who occupy it. The house, as Turner continues, cannot only be seen in terms of the physical, but also relates to the process of developing, and socio-economic mobility of, its inhabitants. Housing is defined as a social, psychological and emotional entity, and is considered as a tool for individuals to settle, with the family and maintain their presence throughout the generations (Erzen, 2006).

The quality of the residential environment is the present value of the measured and unmeasured attributes of housing units and the environment, including the relationships of neighborhood and community in it (Ha and Margaret, 1991). According to Catanese (1979), assessments of the environmental quality of residential housing should include several things. These are the quality of the physical environment, the quality and completeness of the system of municipal services, and the presence of anti-social behaviors that are not too serious, such as crime, vandalism, or similar disorders. In addition, residential environment is also affected by several factors that can determine the quality of it. These are, among others, service facilities, equipment and tools that can support the physical, mental, and social well-being of individuals and families (Mukono, 2000).

Francescato et al. (1979) defines satisfaction as a person's emotional response to a residential dwelling, the positive or negative feelings of the occupants in their residence. Housing satisfaction is a concept used to evaluate the perceptions and feelings of the people about their homes and neighborhoods (Ogu, 2002). Households assess their housing conditions based on the actual situation, and they tend to express high levels of satisfaction with the housing when the housing situation meets the highest standards of comfort living (Teck-Hong, 2011). In addition, housing satisfaction is also used to measure the difference between the actual housing environment and the expected environmental situations (Galster and Hesser, 1981).

\section{Methods}

This research has used a quantitative approach. According to Sarwono (2011: 17) quantitative approach is an approach that emphasizes the importance of the variables as research objects and variables must be defined in 
terms of the operationalization of each variable.These variables are measured with the instrument so that the data consists of numbers that can be analyzed by statistical procedures. A quantitative research has a coherent structure that is the introduction, literature review, methods of research, discussion, and conclusion. Data collection techniques in this research are divided into two ways. They are the collections of secondary data and primary data. Primary data was collected through questionnaires, field observation, and interviews. Secondary data was collected from the literature and data from several agencies. The sampling technique is simple random sampling. The respondents are 100 households. The questionnaires were distributed proportionally based on the number of households as seen in Table 2.

Table 2. Total sample from total population

\begin{tabular}{ccc}
\hline Name of RW & Number of Households & Total Sample \\
\hline RW 15 & 320 & 18 \\
RW 19 & 336 & 18 \\
RW 20 & 301 & 16 \\
RW 21 & 508 & 28 \\
RW 22 & 161 & 9 \\
RW 24 & 202 & 11 \\
Total & 1828 & 100 \\
\hline
\end{tabular}

Method of analysis in this research is descriptive statistics with the analysis of Likert Scale. Variables in this analysis are residents' satisfaction with the quality of the house, the quality of infrastructure, the quality of facilities, and the quality of community relations. The valuation of each variable will result in the value of the benchmark index that represents the quality of the variables. The range of the residents' satisfaction index is shown in Table 3.

Table 3. Residents satisfaction index

\begin{tabular}{ccc}
\hline Range of Satisfaction Index (\%) & Level of Satisfaction & Category \\
\hline $20-34$ & Very Dissatisfied & Very Low \\
$35-49$ & Less Satisfied & Low \\
$50-64$ & Quite Satisfied & Medium \\
$65-79$ & Satisfied & High \\
$\geq 80$ & Very Satisfied & Very High \\
\hline
\end{tabular}

Source :Ogu, 2002

\section{Findings and Discussion}

\subsection{Characteristics of Social Housing Residents}

Sendangmulyo is a social housing built for the low and middle-income community in Semarang. The residents' livelihood is heterogeneous dominated by private employees (58\%). The other kinds are civil servants $(20 \%)$, the informal sector (10\%) and retired persons (12\%) (as seen in Table 4). People who have the jobs in the informal sector are due to their low educational level. It is indicated by the presence of $54 \%$ people who graduated from senior high schools only. The residents of Sendangmulyo have an income between IDR 1,200,000 - 2,500,000 per month, so it can be categorized as a low-income community (see Table 3). The average members of the family are four people, so the income is still, most probably, lacks in sufficing the family needs. The income can only be used for everyday purposes, and there is no money left to repair the house. In general, the houses are in bad condition due to the minimum budget to repair and renovate the houses. 
Table 4. Household Characteristics

\begin{tabular}{|c|c|c|}
\hline Socio-economic characteristics & Number & Percentage $(\%)$ \\
\hline \multicolumn{3}{|l|}{ Education of the household head } \\
\hline Primary School & 6 & 6 \\
\hline Junior High School & 8 & 8 \\
\hline Senior High School & 54 & 54 \\
\hline University Degree and above & 32 & 32 \\
\hline \multicolumn{3}{|c|}{ Employment of the household head } \\
\hline Retired & 12 & 12 \\
\hline Civil servants & 20 & 20 \\
\hline Private Employees & 58 & 58 \\
\hline Informal Sector & 10 & 10 \\
\hline \multicolumn{3}{|l|}{ Income } \\
\hline$<$ IDR $1,200,000$ & 28 & 28 \\
\hline IDR $1,200,001-2,500,000$ & 39 & 39 \\
\hline IDR $2,500,001-5, .000,000$ & 27 & 27 \\
\hline$>$ IDR $5,000,000$ & 6 & 6 \\
\hline \multicolumn{3}{|l|}{ Number of family members } \\
\hline 2 & 2 & 2 \\
\hline 3 & 12 & 12 \\
\hline 4 & 46 & 46 \\
\hline 5 & 32 & 32 \\
\hline$>5$ & 8 & 8 \\
\hline \multicolumn{3}{|l|}{ Status of dwelling ownership } \\
\hline Owned & 85 & 85 \\
\hline Rented & 15 & 15 \\
\hline \multicolumn{3}{|l|}{ Length of stay } \\
\hline$<5$ years & 18 & 18 \\
\hline $5-10$ years & 24 & 24 \\
\hline $10-15$ years & 40 & 40 \\
\hline$>15$ years & 18 & 18 \\
\hline
\end{tabular}

\subsection{Satisfaction in Quality of House}

Sendangmulyo has various types of houses so that people can buy houses that suit their financial abilities. Each type has a specific characteristic in terms of the location, plot area, number of bedrooms, and also the shape of the house. At first, every house had enough yard. However, after being occupied, each family has renovated the house, mostly to add more rooms, so the building coverage has increased. The types of house in Sendangmulyo can be seen in Figure 2. 


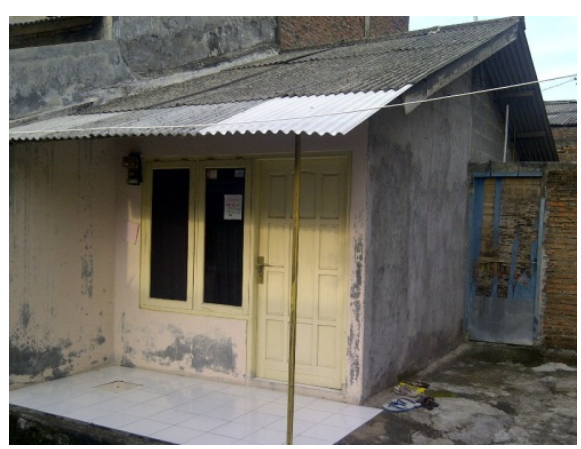

Figure 2. 21-house types

The main differences among the house types, as shown above, are the plot and house areas. The house areas for -Type-21, Type- 36 and Type- 45 are 21 square meters, 36 square meters, and 45 square meters respectively. Each type of house has a plot area, of 60 square meters for Type-21, 84 square meters for Type-36, and 180 square meters for Type-45. Most of these houses are built using concrete block building materials and asbestos roof to reduce the cost of house construction. The small size of the plots has resulted in not all house in Sendangmulyo has enough yard. The analysis showed that $56 \%$ of people have not had a yard again. For example, many houses of the small size type (21 square meters) are only capable of being used to stay by the occupants with no yard at all to put the vehicles.

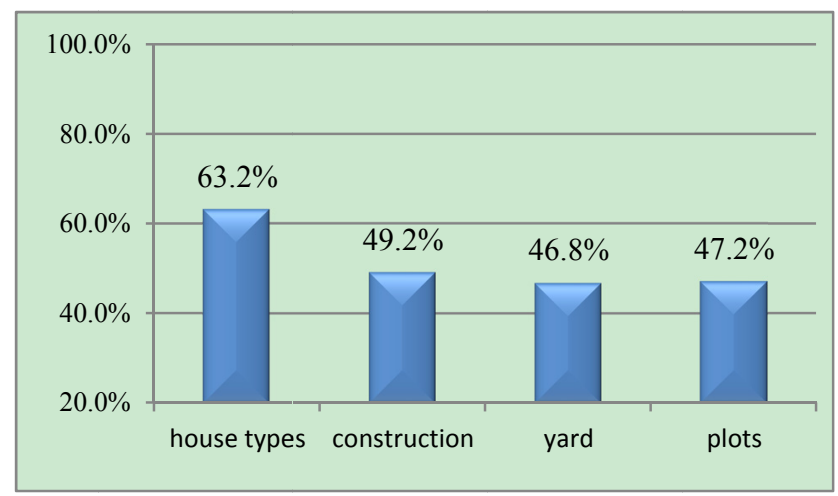

Figure 3. Satisfaction of house's quality

The level of satisfaction with the quality of the house is, on average, quite satisfied with the satisfaction index of $51.6 \%$ (Table 6). The highest share of the index is from the satisfaction with the house types $(63.2 \%)$ while satisfaction with the quality of the yard is the lowest share, $46.8 \%$ (see Figure 3 ). The satisfaction with the quality of the yard has a small value because many occupants have expanded the building coverage so that they do not have yards anymore (Figure 3). The building structure has already been stable because many of the houses $(73 \%)$ have been renovated while the others $(27 \%)$ are still in the original structure built by PERUMNAS.

The somewhat low level of satisfaction with the quality of the houses shows that the supply of houses in Sendangmulyo is not fully matched to the needs of the residents. Houses provided by PERUMNAS have very small areas with only two to three rooms available whereas the average number of families are four to five people. Families with many children feel the bedrooms are not enough. They have to renovate the house to increase the number of rooms either horizontally or vertically.

In addition, there are also many houses that have been left empty, unoccupied and damaged, which reached 114 units or $5.5 \%$ of the total houses in the Sendangmulyo. This high rate of unoccupied houses shows that many of the residents are still less satisfied with the quality of their houses, so that they chose to move to other places with better conditions.

\subsection{Satisfaction in Quality of Infrastructure}

The roads in Sendangmulyo are in various width, i.e. 2 meters, 4 meters, 6 meters, and 8 meters. Generally, the conditions of the roads are quite good because they are made of paving blocks. However, there are small and 
damage roads in several locations. Small roads (2 meters) are there in the Type-21 blocks (Figure 4) while the wider roads are in the Type-36- and Type-45- blocks.

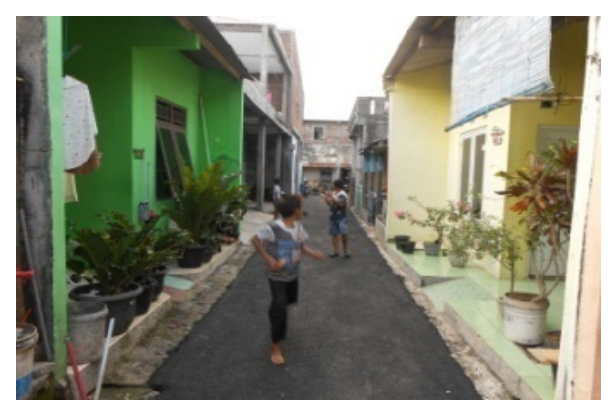

Figure 4. 2 meters roads at RW 21

The drainage in Sendangmulyo housing consists of two types: open drainage and closed drainage. The closed drainage is applied to the major roads, especially in the shopping area of Bukit Bougenville Road while open drainage is for the pathways and neighborhood roads. The domestic waste in Sendangmulyo is transported to the waste disposal sites routinely. It is done by the officers who are paid through the monthly social fund by the neighborhood institution (RT). There are also two landfills in Sendangmulyo that serve the waste from residents in RW 21 and RW 19. Meanwhile, clean water in Sendangmulyo is supplied by the City's Clean Water Company (PDAM). However, the water quality is poor because it contains a lot of calcium so that people have to buy drinking water for their daily cooking.

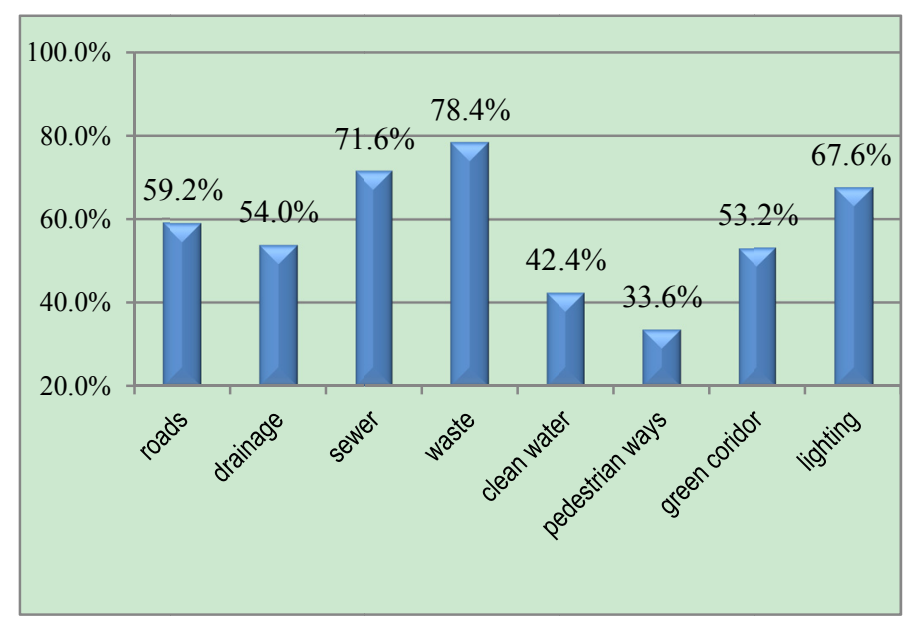

Figure 5. Satisfaction of the quality of environmental infrastructure

In the quality of infrastructure, the level of residents' satisfaction is quite satisfied with $57.6 \%$ of satisfaction index (Table 6). From all the indicators, the waste management service shares the highest $(78.4 \%)$ while the lowest share is from the pedestrian pathway, with the index value of $33.6 \%$ (see Figure 5). The indicator of waste management services has a high value because of Sendangmulyo has a good waste management. It is because there are two temporary landfills and the waste from the residents has been transported routinely. The satisfaction of the pedestrian quality is low because there are no pedestrian pathways in Sendangmulyo.

\subsection{Satisfaction in Quality of Facilities}

Worship facilities in Sendangmulyo Housing are complete. There are thirteen small mosques scattered in each of the neighborhood units. Also, there is a big mosque, Jami 'Al-Qodar, which becomes the primary worship facility for the Moslem community in Sendangmulyo (see Figure 6). Meanwhile, the shopping facilities in Sendangmulyo consist of small shops, stores, and a temporary marketplace ("Pasar Krempyeng"). Sendangmulyo also has medical facilities such as clinics, general practitioners, midwives, and a community health care (POSYANDU). 


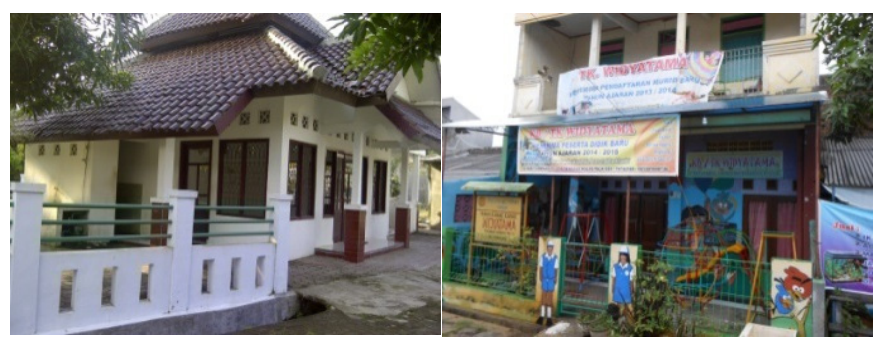

(a)

(b)

Figure 6. (a) Mosque at RT 6 RW 15; (b) Playgroup and Kindergarten at RT 12 RW 21

However, only two community halls are there, one in RW 19 and the other one in RW 21. Every hall is well utilized by the responding RW community for social activities. Also, Sendangmulyo only has limited facilities for early education. There are only five kindergarten units and a playgroup scattered in RW 20 and RW 21. In addition, Sendangmulyo also has sports facilities such as sports fields utilizing land allocated for public facilities that has not been built and some space on the roads. As for security facilities, there is a security post in every RW built by the responding residents.

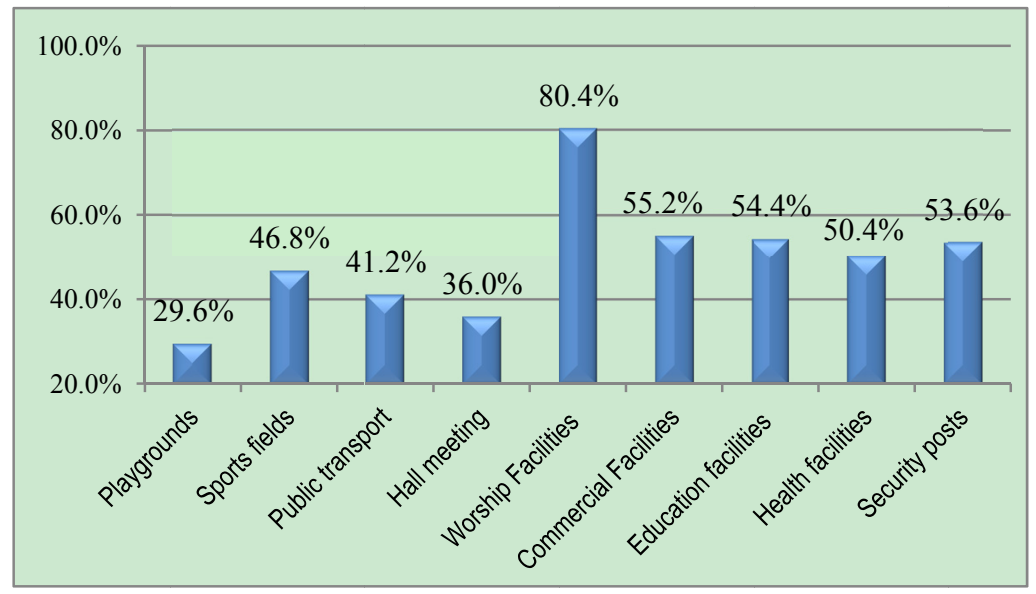

Figure 7.Satisfaction of the quality of facilities

The level of residents' satisfaction with the quality of facilities is categorized less satisfied, with an index of 49.7\% (Table 6). From all the related indicators, the lowest share is from the satisfaction with children's playgrounds while the highest satisfaction is from the quality of worship facilities (see Figure 7). The indicator of kids' playgrounds has the lowest index (29.6\%) because Sendangmulyo does not have enough playgrounds so that many children are playing in the neighborhood streets and yards.

The highest satisfaction is there for the quality of worship facilities. It is because, as mentioned, there are many facilities for Moslems to worship scattered in every neighborhood unit. Meanwhile, for education facilities, there are only facilities for early childhood education (playgroups) and kindergartens while for elementary schools, junior high schools, and senior high schools have not been available yet. Similarly, for medical facilities there are only available clinics, doctor, and midwives who work in a mother -child community health care (POSYANDU). PERUMNAS has planned to build a medical center in Sendangmulyo, but until now PERUMNAS just only provides land allocated for it. As for public transport facilities, Sendangmulyo is only served by the medium-sized bus with low frequency of service. The bus only serves five to eight times daily, so the residents are less satisfied with the public transport facility.

\subsection{Satisfaction in Quality of Community Relations}

The quality of community relations is measured through four indicators, i.e. neighborly relations, environmental security, social activities, and local institution. Sendangmulyo was built with small and 
close-to-each-other plots leading to good and tightly community relations. The residents still often gather in groups around their houses and talk to each other, especially during the afternoon and early evening. The monthly social activities in every RT make people more familiar, and they can get to know each other. Types of social activities in Sendangmulyo are diverse and different from each other in every RW. Social activities such as meetings in the RT, Moslem prayers recitation, mother and child health care, family welfare improvement (PKK), and other social activities are still there routinely every month. In addition, the existence of the night patrolling activities also makes the neighborhood units in Sendangmulyo more secure.

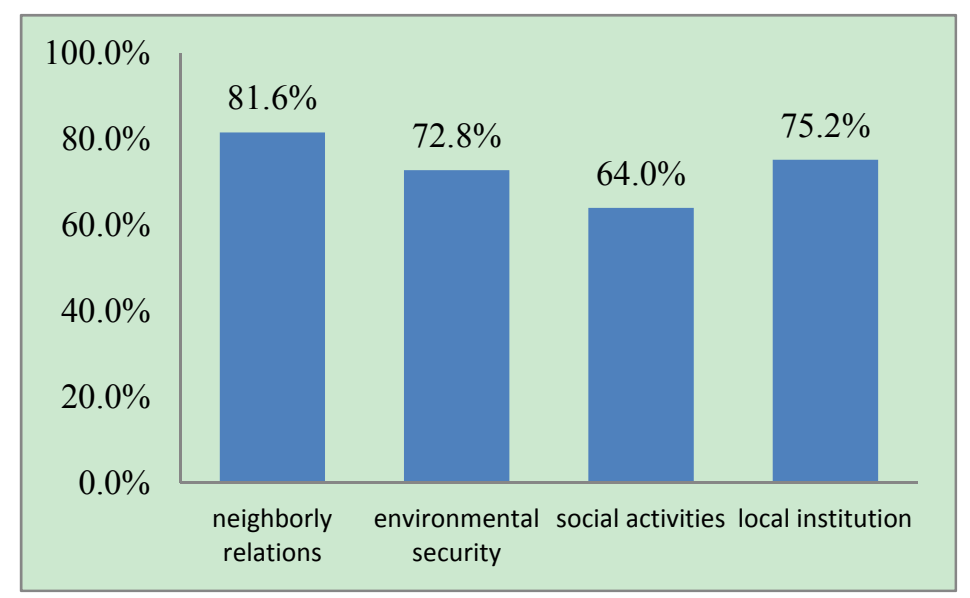

Figure 8. Community relations quality satisfaction

Table 5. Social Interaction

\begin{tabular}{lll}
\hline Social Interaction & Number & Percentage (\%) \\
\hline Number of persons they know in their neighborhood & 74 & 74 \\
All of the neighbors & 23 & 23 \\
Almost all of the neighbors & 2 & 2 \\
Half of the neighbors & 1 & 1 \\
Very few of the neighbors & & \\
Frequencyof visits to neighbors in the same neighborhood & 2 & 11.8 \\
At least once in a month & 1 & 5.9 \\
At least 2-3 times in a month & 14 & 82.4 \\
At least once in a week & & \\
Frequencyof visits to neighbors in the outside of own neighborhood & 5 & 29.4 \\
At least once in a month & 4 & 23.5 \\
At least 2-3 times in a month & 8 & 47.1 \\
At least once in a week & & \\
Discussions with neighbors about environmental issues & 1 & 5.9 \\
Never & 2 & 11.8 \\
Sometimes & 14 & 82.4 \\
\hline
\end{tabular}

The level of residents' satisfaction with the quality of community relations is high with the satisfaction index of $73.4 \%$ (Table 6). Among all the indicators used, the lowest satisfaction index is the indicator of social activities while the highest index is neighborly relations (see Figure 8). The low value of social activity is probably due to the decreasing intensity of social activities in this modern area. Social activities such as night patrolling, environmental cleanings, and sports activities have begun to decrease because of the busyness of each resident. 
The high satisfied level of neighborly relations appears from the number of people who can recognize their neighbors outside their RTs. The high percentage of people who know many of neighbors over their RTs (74\%) (see Table 5) is potential to create a harmonious environment. It is apparent that the sense of community and kinship care is still very good. This aspect is an important factor so that the residents will be comfortable to live at Sendangmulyo Housing. In addition, the active community activities such as environmental cleanliness, mother and child health care, social gatherings, and Moslem prayers recitation performed routinely on each RT and RW contribute to good community relations. Neighborly relations and social activities are still very good because of the performance of the local institutions in Sendangmulyo as perceived by the people as very good.

\subsection{Satisfaction in Social Housing}

The overall residents' satisfaction level in Sendangmulyo is measured by synthesizing all indices of the variables involved. The satisfaction variables are, as discussed previously, the quality of the house, the quality of infrastructure, the quality of facilities and the quality of community relations.

Table 6. Resident's satisfaction index in social housing

\begin{tabular}{cccc}
\hline Variable & Total Score & Satisfaction Index (\%) & Category \\
\hline Quality of houses & 258 & 51.6 & Quite satisfied \\
Quality of infrastructure & 288 & 57.6 & Quite satisfied \\
Quality of facilities & 249 & 49.8 & Satisfied \\
Quality of community relations & 367 & 73.4 & Satisfied \\
Average & 290.5 & 58.1 & Quite satisfied \\
\hline
\end{tabular}

Based on the synthesis done for the overall indices of satisfaction, it has a total score of 290.5 with the index of $58.1 \%$. It means that the level of residents' satisfaction in Sendangmulyo is quite satisfied. The highest satisfaction level is the quality of community relations, and the lowest one is the quality of facilities. This overall satisfaction of the residents of Sendangmulyo can be said as relatively low because the index is less than $60 \%$. The low satisfaction has an impact on some residents that have started to move to other places for a better living. It causes many unoccupied houses that are not in a good condition, rented, and have been damaged and poorly maintained. It is greatly ironic that the social housing like Sendangmulyo built by the PERUMNAS are not fully occupied while there are many people still cannot live in a livable housing.

Residents assess their housing conditions based on what they feel with the actual situation. They tend to express high levels of satisfaction with when the housing situation meets the highest standards of comfort living (Teck-Hong, 2011). It is reasonable then, the somewhat low level of residents' satisfaction in Sendangmulyo indicates that the environmental facilities have not fully met the standards of comfort living for the residents. It is one of the factors contributing to the low public interest to occupy a house in Sendangmulyo. It is apparent from the number of empty and unoccupied houses that have reached 114 units, besides the $14.5 \%$ of undeveloped plots in Sendangmulyo Housing.

The highest residents' satisfaction in Sendangmulyo is influenced by the quality of community relations that until now neighborly relations and harmony among the residents are very good. It becomes an important social factor in realizing harmonious housing in the future. Although in the present there are still problems in the environment facilities, either lacking or poorly maintained, and also the problem of poor quality of the house structure, but many residents remain to stay at their houses in the neighborhood because of this social factor.

\subsection{Social Housing Policy In The Future}

From the study, it has been found that the implementation of the social housing policy by PERUMNAS based on the residents' satisfaction is quite satisfied (58.1\% satisfaction rate). The residents' satisfaction is supported by mainly the social factor, i.e. the good community relations. But the residents have low satisfaction with the quality of the houses and facilities because of inadequate residential facilities provided by the PERUMNAS. Despite the problems faced, the majority of residents still survive and remain to live in Sendangmulyo due to the good community relations.

Therefore, this kind of social housing policy should be continued in the future; however, it is necessary to improve the environmental quality, the quality of infrastructure and facilities, as well as the social quality. The future of social housing development should also pay attention to affordability, targeting accuracy for 
low-income communities, the accessibility to the place of work and other facilities. With a good neighborhood environment and equipped with complete infrastructure facilities, the residents will be to stay so that their tendency to move is minimized.

\section{Conclusion}

The level of residents' satisfaction in Sendangmulyo is quite satisfied with the index of $58.1 \%$ (the median is $60 \%$ ). The highest level of satisfaction is in the variable of the quality of community relations. Good and tightly community relations become the major factor of social housing that makes residents able to survive. The lack of public facilities such as education facilities, medical facilities, marketplaces, and playgrounds in Sendangmulyo has resulted in the less satisfied category of the quality of facilities. The poor quality of water supply, damaged roads, improper pedestrians, and poorly maintained drainage have resulted in the quite satisfied category of the infrastructure quality. The residents' satisfaction level based on the quality of the house is quite satisfied. It is because the medium standards of building construction applied by PERUMNAS so that almost every family should renovate the house to improve their comfort.

It is apparent then that factors affecting the levels of satisfaction in Sendangmulyo are four. They, sequentially from the most to the least influencing, are the quality of community relations, the quality of environmental infrastructure, the quality of houses, and the quality of public facilities. That is why, it is necessary to ensure the minimum standards and the completeness of housing facilities to make a better living for the low-income communities. By and large, with the house quality limitations and poor infrastructure conditions, the quality of community relations becomes the major factor in residents' satisfaction to live and survive in the Sendangmulyo neighborhood. Therefore, environmental factors should be the top priority for consideration in the provision of social housing in the future. With a good environment and complete infrastructure facilities, the residents will be satisfied to stay so that their tendency to move are small.

\section{Acknowledgments}

The authors would like to express their gratitude to the Engineering Faculty and the Department of Urban and Regional Planning at the Diponegoro University, Semarang for all the facilities provided for this research. The authors would also like to offer special thanks to all people and community of Sendangmulyo Housing, The Sendangmulyo Sub-district Administration, and the National Housing Authority of Indonesia (PERUMNAS) for providing information, data, and support for this research.

\section{References}

Altas, N. E., \& Ozsoy, A. (1997). Spatial Adaptability and Flexibility as Parameters of User Satisfaction for Quality Housing. Building and Environment, 33(5), 311-323.

Amerigo, M., \& Aragones, J. I. (1997). A theoretical and methodological approach to the study of residential satisfaction. Journal of Environmental Psychology, 17, 47-57. http://dx.doi.org/10.1006/jevp.1996.0038

Budiharjo, E. (1998). Percikan Masalah Arsitektur perumahan Perkotaan. Yogyakarta: Gadjah Mada University Press.

Catanese, A. J., \& Snyder, J. C. (1979). Introduction to Urban Planning. Newyork : McGraw-Hill.

Erzen, J. N. (2006). Aesthetics of the environment. METU Foundation of Environmental. Development Company Inc.

Francescato, G. et al. (1979). Resident's Satisfaction in HUD-Assisted Housing: Design and Management Factors. Washington DC: U.S. Department of Housing and Urban Development.

Galster, G. C., \& Hesser, G. W. (1981). Residential satisfaction: Compositional and contextual correlates. Environment and Behaviour, 13(6), 735-758. http://dx.doi.org/10.1177/0013916581136006

Ha, M., \& Weber, M. J. (1991). The Determinants of Residential Environmental Qualities and Satisfaction: Effect of Financing, Housing Programs, and Housing Regulations. Housing and Society, 18, 65-76.

Hablemitoglu, S. (2010). The Assesment of the Housing in the Theory of Maslow's Hierarchy of Needs. European Journal of Social Sciences, 16(2), 214-220.

Hashim, A. E. et al. (2012). Assessing Factor Influencing Perfomance of Malaysian Low-Cost Public Housing in Sustainable Environment. Procedia-Social and Behavioral Sciences, 50, 920-927. http://dx.doi.org/10.1016/j.sbspro.2012.08.093

Jiboye, A. D. (2011). Evaluating Public Housing Perfomance: Providing a Basis for Residential Quality Improvement in Nigeria. Middle-East Journal of Scientific Research, 9(2), 225-232. 
Jiboye, A. D. (2012). Post-occupancy Evaluation of Residential Satisfaction in logos, Nigeria: Feedback of Residential Improvement. Frontiers of Architectural Research, 1, 236-243. http://dx.doi.org/10.1016/j.foar.2012.08.001

Kredit Pemilikan Rumah, Bank Tabungan Negara (KPR-BTN). (2007). Ketentuan Minimum Proyek Perumahan dan Rumah Sederhana.

Lara, T., \& Bekker, M. C. (2012). Resident Satisfaction as a Project Wuality Measure: The Case of Nova Vida Housing Project, Angola. Jurnal of Contemporary management, 9, 364-381.

Mohit, M. A., \& Azim, M. (2012). Assesment of Residential Satisfaction with public Housing in Hulhumale, $\begin{array}{lllll}\text { Maldives. } & \text { Procedia-Social and Behavioral }\end{array}$ http://dx.doi.org/10.1016/j.sbspro.2012.08.078

Mori, K., \& Christodoulou, A. (2011). Review of Sustainability Indices and Indicator: Towards a New City Sustainability Index (CSI). Environmental Impact Assessment Review, 32, 94-106. http://dx.doi.org/10.1016/j.eiar.2011.06.001

Mukono, H. J. (2000). Prinsip Dasar Kesehatan Lingkungan. Surabaya: Airlangga University Press.

Narbuko, C., \& Achmadi, H. A. (2007). Metodologi Penelitian. Jakarta: Bumi Aksara.

Ogu, V. I. (2002). Urban residential satisfaction and the planning implications in a developing world context: the example of Benin City, Nigeria. International Planning Studies, 7(1), 37-53. http://dx.doi.org/10.1080/13563470220112599

Panuju, B. (1999). Pengadaan Perumahan Kota dengan Peran serta Masyarakat Berpenghasilan Rendah. Bandung: Alumni.

Salleh, A. G. (2008). Neighborhood Factor in Private Low-cost Housing in Malaysia. Habitat International, 32, 485-493. http://dx.doi.org/10.1016/j.habitatint.2008.01.002

Teck-Hong, T. (2011). Housing Satisfaction in Medium and High-cost Housing: The Case of Greater Kuala Lumpur, Malaysia. Habitat International, (36), 108-116.

Toscano, E. V., \& Amestoy, V. A. (2008). The relevance of social interactions on housing satisfaction. Social Indicators Research, 86(2), 257-274. http://dx.doi.org/10.1007/s11205-007-9107-5

Turner, J. (1976). Housing by People. London: Marion Boyar Publiser Ltd.

Winston, N., \& Eastaway, M. P. (2007). Sustainable Housing in the Urban Context: International Sustainable Development Indicator Set and Housing. Social Indicators Research, 87, 211-221. http://dx.doi.org/10.1007/s11205-007-9165-8

Yuliastuti, N., \& Said, F. R. D. (2013). Mass Housing Sustainability Based on Community Cohesion (A case study at Sendangmulyo, Indonesia). Journal Procedia Envrionmental Sciences, 17, 814-821.

Yuliastuti, N., \& Saraswati, N. (2014). Environmental Quality in Urban Settlement: The Role of Local Community Association in East Semarang Sub-District. Journal Procedia Social and Behavioral Sciences, 135, 31-35.

\section{Copyrights}

Copyright for this article is retained by the author(s), with first publication rights granted to the journal.

This is an open-access article distributed under the terms and conditions of the Creative Commons Attribution license (http://creativecommons.org/licenses/by/3.0/). 